\title{
AMOR, MEDO E SALVAÇÃO: APROXIMAÇÕES ENTRE VALDOMIRO SILVEIRA E GUIMARÃES ROSA
}

\author{
Suzi Frankl Sperber*
}

De sorte que la littérature qui se contente de "décrire des choses", d'en donner seulement un misérable relevé de lignes et de surfaces, est celle qui tout en s'appellant réaliste, est la plus éloignée de la réalité, celle qui nous appauurit et nous attriste le plus, car elle coupe brusquement toute communication de notre moi présent avec le passé, dont les choses gardaient l'essence, et l'avenir, où elles nous incitent à la goûter de nouveau!.

RESUMO: Valdomiro Silveira reduz sua narrativa "Salvaçāo" à história de animais, sem ser uma fábula, $e$ inclui-se no conjunto de obras que, para evitar a explicitação do erotismo, encobre o amor com medo. "A hora e vez de Augusto Matraga" não camufla o erotismo e dá sentido à personagem e ao texto, aproveitando como forma a saga nordestina (cordel), a história de vida de santos, o tema do "Judeu Enrante" e a parábola. A força dos contos de Sagarana advém do sistemático aproveitamento dos pequenos gêneros, que se encontram na oralidade e que servem de base tanto para a produçăo, como para a recepção de textos ou de enunciaçōes. A oralidade, que serve para mostrar o caipira como capaz de espiritualidade profunda, é também recurso manutensor do segredo religioso.

UNITERMOS: Regionalismo; oralidade; formas simples; amor e medo; literatura comparada.

- Professora do Departamento de Teoria Literária do IEL/UNICAMP.

1. PROUST, Marcel. A la recherche du temps perdu. Texte en partie inédit, établi sur les manuscrits autographes. Variantes, notes critique, introduction, résumé de chaque partie de l'oeuvre, index des noms de personnages et des noms de lieux, chronologie de Marcel Proust par Pierre Clarac et André Ferré. Préface d'André Maurois. Paris, Gallimard (NRF), 1954. v. 3, p. 885. (Bibliothèque de la Pléiade). 
Alphonse Daudet ${ }^{2}$, autor de Lettres de Mon Moulin ${ }^{3}$ e de Tartarin de Tarascon ${ }^{4}$, foi quem suscitou a expressăo "regionalista", por basear-se em costumes e tradiçōes regionais. (Suas personagens - como o próprio Tartarin - típico fanfarräo - movem-se em um universo localizado na Provence, sul da França). No Brasil, a estética romântica incluiu como tema o amor às raízes nacionais, o que era propício para ser desenvolvido no Brasil imediatamente depois da Independência, momento em que já se buscava diferenciar a produção brasileira da portuguesa. Esta diferenciação criava um conflito entre o desejo de ser ele mesmo e o desejo de ser o outro, cosmopolita. Talvez por nāo apresentar para críticos e historiadores da literatura o mesmo impasse entre o anseio pelo outro, universal, cosmopolita e a caracterizaçāo diferenciada de si próprio, obras portuguesas como A Morgadinha dos Canaviais, que descreve uma região de Portugal, não foi considerada regionalista. No Brasil, além de o tema do interior rural ou sertanejo ter atraído diversos autores ${ }^{5}$, a vergonha do mundo rural e sertanejo talvez tenha contribuído para caracterizar nossa literatura numa oposição construída em torno do binômio campo-cidade $e$ regional-universal, subentendendo-se um no outro (regional e campo; universal $e$ cidade). O Manifesto Regionalista de Gilberto Freyre, publicado em 1926, sem dúvida sedimentou essa caracterização de uma certa produçăo literária brasileira.

Quando Guimarāes Rosa publicou Sagarana, em 1946, foi considerado "um novo Valdomiro Silveira", isto é, um autor regionalista. Pouco tempo depois, mas ainda em 1946, foi publicado o artigo de Antonio Candido 6 , em que o crítico mostra as diferenças entre Sagarana de Rosa $e$ a produçăo regionalista:

"A província do Sr. Guimarāes Rosa, - no caso Minas é menos uma regiāo do Brasil do que uma região da arte, com detalhes e locuçöes e vocabulário e geografia cosidos de maneira por vezes irreal, tamanha é a concentração com que trabalha o autor $[$... Por isso, sustento, e sustentarei mesmo que provem o meu erro, que Sagarana nāo é um livro regional como os outros, porque nāo existe regiāo alguma igual à sua, criada livremente pelo autor com elementos caçados analiticamente e, depois, sintetizados na ecologia belíssima das suas histórias [...]

"Sagarana nasceu universal pelo alcance e pela coesão da fatura. A língua parece finalmente ter atingido o ideal da expressão literária regionalista. Densa, vigorosa, foi talhada no veio da linguagem popular e disciplinada dentro das tradiçōes clássicas"”.

Hoje, no cinqüentenário da publicação de Sagarana, ninguém mais se atre-

2. Nasceu em Nîmes, em 13 de malo de 1840 e morreu em Paris em 16 de dezembro de 1897.

3. Publicado em 1869.

4. Publicado em 1872.

5. A partir do Visconde d'Escragnole Taunay, com seu romance Inocéncia.

6. CANDIDO, Antonio. Sagarana. In: COUTINHO, Eduardo F. (org.). Guimarães Rosa. Rio de Janeiro, Civilização Brasileira/Brasilia, INL, 1983. p. 243-7.

7. Idem, Ibidem. p. 244-5. 
veria a qualificar a obra de regionalista. Reconhece-se a sua universalidade e magnitude. Mas por que houve confusão? Por que os críticos em geral nāo souberam avaliar a diferença de qualidade entre os dois autores? Por que a explicitação da grandeza de um texto é de difícil verbalizaçăo e análise? Talvez para esclarecer alguns pontos valha a pena pensar na questão do regionalismo, assim como explicitar as "tradiçōes clássicas e a linguagem popular" e os "detalhes e locuçōes e vocabulário e geografia cosidos de maneira por vezes irreal", de Antonio Candido. Para retomar o tema do regionalismo, compararei Valdomiro Silveira a Joăo Guimarāes Rosa, porque existem dois contos que contêm uma fímbria de semelhança: "Salvação", de Valdomiro Silveira ${ }^{8}$ "A hora e vez de Augusto Matraga", de João Guimarães Rosa?.

O meu intuito não é o de verificar as diferenças, que sempre existem entre textos e autores diferentes. Quero propor que a força dos contos de Sagarana advém do sistemático aproveitamento de formas simples, ou dos pequenos gêneros, no dizer de Jauß ${ }^{10}$ que se encontram na oralidade e que servem de base tanto para a produção, como para a recepção de textos ou de enunciaçōes.

Entendo as formas simples com o sentido apresentado por André Jolles ${ }^{11}$ : noçöes não abrangidas nem pela estilistica, nem pela retórica, nem pela poética, ainda que possam ser utilizadas por todas elas. Encontram-se na oralidade e na escrita, mas provêm da oralidade. Sāo pré-literárias, precedendo as manifestaçōes realizadas historicamente na cultura literária e virtuais, podendo realizar-se ou nāo, escolhidas por autores conforme o seu código cultural literário, social e histórico. São blocos de sentido e forma encontráveis em variantes e seqüências da açăo relatada ficcional e historicamente. Correspondem a uma experiência pré-literária caracterizada fundamentalmente pelo esforço em atribuir um sentido global, de totalidade, a um fenômeno ou um conjunto deles. Reúne eventos que tematizam a realidade interna e externa do ser humano, porém de modo a superar o limite do instante e do fragmento. A atribuiçăo de sentido à vida é representada por uma das formas simples, que, cada uma delas, tem nuances de função e sentido. Estão disponíveis para todo o ser humano, tanto para a produção como para a recepçäo, apresentando-se como conditio sine qua non da interculturalidade, dando forma ao imaginário que, no dizer de Lacan, é inato. Nāo sāo formas fechadas, cristalizadas e imutáveis. Permitem inclusōes e mudanças, sempre a partir de referências que facilitam a recepção e produção e que servem tanto para confirmar uma função e forma, como para negá-la. A positividade e a negatividade são agenciadas pela

8. SILVEIRA, Valdomiro. "Salvaçāo". In: Os caboclos. Notas biográficas de Jônia Silveira Gonçalves e carta de Agenor Silveira. 4. ed. Brasilia, Civilizaçăo Brasileira, 1975.

9. ROSA, Joăo Guimaräes. "A hora e vez de Augusto Matraga". In: Sagarana. 6. ed. Rio de Janeiro, J. Olympio, 1964.

10. JAUß, Hans Robert. Alterltät und Modernität der Mittelalterlichen Literatur. München, Wilhelm Fink, 1977.

11. JOLLES, André. Formas simples: legenda, saga, mito, adiuinha, ditado, caso, memoráuel, conto, chiste. Trad. Álvaro Cabral. São Paulo, Cultrix, 1976. 
linguagem, assim como as formas simples se constituem na própria linguagem: "[...] a própria linguagem é um principio de cultura, de fabricação e de interpretação, no qual se produz, com a maior especificidade, a vinculação a uma determinada ordem"12.

"Salvação", como quase todos os contos de Os Caboclos (salvo "Desespero de Amor") foi escrito entre 1897 e 1906. Além de chamar-se "Salvação", relacionável tanto à salvação dos animais, no conto de Silveira, como a de Augusto Matraga, o conto apresenta a frase de Albino, comovido, "reparando na verdura imóvel dos arvoredos": "- Eu também já tive o meu dia, e dia grande!"13.

"A hora e vez de Augusto Matraga" foi uma das "histórias [...] começadas e acabadas no formoso anno de 1937, precisamente entre 20 de maio e 4 de dezembro" ${ }^{14}$, que compunham o volume Sezäo, encaminhado para concurso literário em 1937. Publicado mesmo, já refeito e com o título que conhecemos (o título anterior era "A opportunidade de Augusto Matraga"), o conto o foi em 1946, enquanto que a publicaçăo em livro de "A Salvação" aconteceu em 1920. A frase de Albino referida acima é comparável, em "Matraga", ao título do conto, e a: "Cada um tem a sua hora e a sua vez: você há de ter a sua."15; "E a minha vez há de chegar..."16; "Cada um tem a sua vez, e a minha hora há-de chegar!..."7; "Sou um desgraçado, māe Quitéria, mas o meu dia há-de chegar!... A minha vez... ${ }^{18}$; "- Cada um tem a sua hora, e há-de chegar a minha vez!" ${ }^{19}$; "Adeus, minha gente, que aqui é que mais não fico, porque a minha vez vai chegar, e eu tenho que estar por ela em outras partes!" 20 . Ainda que a idéia de ter seu dia, isto é, a sua hora e vez, seja a mesma, Rosa cunhou a expressão que hoje pertence ao povo, no Brasil, (hora e vez) e a expressão é variada e tematizada no conto, de modo a que "A hora e vez de Augusto Matraga" esteja na expectativa e esperança, com o acontecimento propriamente dito colocado no futuro, enquanto que Albino pronuncia a frase com o acontecimento já passado. É auto-satisfaçāo. O grande acontecimento, para Matraga, se dá no fim da narrativa e é apenas marcado pela sua indescritivel alegria.

A personagem principal do conto de Valdomiro Silveira salva uns passarinhos de serem comidos por uma cobra-cipó, mas acaba salvando também a cobra, para salvar os passarinhos todos que estavam ao seu alcance, um deles, um gurundí, já hipnotizado e entregue à sorte (isto é, à cobra-cipó). Albino comove-se consigo mesmo, por sua magnanimidade. Nhô Augusto Matraga é salvo por um casal de negros, num primeiro plano (físico); por um padre, num outro plano (espiritual) e finalmente por Deus, ajudado por seu empenho pessoal, no plano mistico.

12. Idem, ibidem. p. 25.

13. SILVEIRA, Valdomiro. Op. cit., p. 62-7.

14. Anotação do Autor ao fim do manuscrito de 1937.

15. ROSA, Joāo Guimaräes. Op. cit., p. 336.

16. Idem, ibidem. p. 337.

17. Idem, tbidem. p. 341 .

18. Idem, ibidem. p. 342 .

19. Idem, Ibidem. p. 352 .

20. Idem, tbidem. p. 354 . 
Valdomiro Silveira descreve as aves, ou a natureza assim:

1. "Um gurundi pegara a chiar, muito aflito, no meio do cambuizal: e perto dele, em gritaria alvoroçada, enrufando as penas, iam pelo ar os bem-te-vis, as cabeçudas $e$ as sapucaias. Chegou a aparecer no tumulto, curiosa e assustada, u'a meia-pataca: mas, pousando em galho vizinho ao em que estava o gurundi, tomou-se logo de tamanho terror, que abriu o vôo, desmanchado e cor de havana, entre os ramos povoados de frutinhas vermelhas"21.

Segundo Carmem Lydia de Souza Dias ${ }^{22}$, Valdomiro Silveira "premido pela necessidade intima de comparecer na obra com a sua personagem caipira, para quem os espetáculos admiráveis da natureza seriam habituais ou, pelo menos, rotineiros, (...) frequientemente lança māo de descriçōes de cenas naturais" ${ }^{23}$. Mais adiante ela refere a natureza freqüentemente humanizada $e$ o papel atribuido aos pássaros em toda a obra de Valdomiro Silveira ${ }^{24}$.

Em "A hora e vez de Augusto Matraga", de Guimarães Rosa, uma descriçăo de aves tem o seguinte sabor:

II. "Até que, pouco a pouco, devagarinho, imperceptivel, alguma cousa pegou a querer voltar para ele, a crescer-lhe do fundo para fora, sorrateira como a chegada do tempo das águas, que vinha vindo paralela: com o calor dos dias aumentando, e os dias cada vez maiores, e o joāo-de-barro construindo casa nova, e as sementinhas, que hibernavam na poeira, esperando na poeira, em misteriosas incubaçōes. Nhô Augusto agora tinha muita fome e muito sono. $O$ trabalho entusiasmava e era leve. Não tinha precisāo de enxotar as tristezas. Nāo pensava nada..." ${ }^{25}$

III. "E agora os periquitos, os periquitinhos de guinchos timpânicos, uma esquadrilha sobrevoando outra... E mesmo, de vez em quando, discutindo, brigando, um casal de papagaios ciumentos. Todos tinham muita pressa: os únicos que interromperam, por momentos, a viagem, foram os alegres tuins, os minúsculos tuins de cabecinhas amarelas, que nāo levam nada a sério, e que choveram nos pés de mamão e fizeram recreio, aos pares, sem sustar o alarido - mrl-mill!rrl-rrril!...

"Mas o que nāo se interrompia era o trănsito das gámulas maitacas. Um bando grazinava alto, risonho, para o que ia na frente: - Me espera!... Me espera!... - E o grito tremia e ficava nos ares, para o outro escalăo, que avançava lá atrás.

21. SILVEIRA, Valdomiro. Op. cit., p. 64.

22. DIAS, Carmem Lydia de Souza. Paixōo de raiz: Valdomiro Silueira e o regionalismo. São Paulo, Ática, 1984.

23. Jdem, ibidem. p. 158.

24. "Funcionam quase sempre como motivos de comparação com os seres humanos, como marcos de referência temporal e espacial, como simbolos de bons e maus presságios ante o desencadear-se da açăo dramática e até mesmo como elementos peso no enfoque anti-romântico da natureza, que o autor procura imprimir em certas passagens. (Idem, ibidem. p. 161-2).

25. ROSA, Joāo Guimarães. Op. cit., p. 342. 
"- Virgem! Estăo todas assanhadas, pensando que já tem milho nas roças... Mas, também, como é que podia haver um de-manhā mesmo bonito, sem as maitacas?!..."26.

O texto I, de Valdomiro Silveira, tem como personagens os pássaros que se agitam (gurundi, bem-te-vi, sapucaia, meia-pataca). A açäo transcorre no meio do cambuizal, cheia de afliçāo, alvoroço (que poderia ser de alegria), susto, terror. Predomina susto e medo. Mas o conto traz o título "salvação", palavra mais aplicável à alma ou espirito, do que ao corpo, enquanto "salvamento" é aplicável ao corpo. As aves têm medo. O parágrafo seguinte continua falando de aves, mas com um ritmo variável, oscilante entre rebuliço e serenar, perseguição e vitória. Como sāo parágrafos iniciais, representam toda a ação da narrativa e correspondem a uma promessa de enredo, um tanto aquém da idéia de salvação.

A ação, em $M .{ }^{27}$ inicia-se no $2^{\circ}$ parágrafo. No $1^{\circ}$, a personagem principal é apresentada (à p. 319 ). Ả p. 342 já transcorreu bom pedaço da história e o movimento das aves simboliza os novos horizontes que se abrem aos poucos para a personagem, quando as barreiras internas de Matraga caem. A descriçāo vale pelo que refere como cifra. Os animais metaforizam movimento, som, alegria, vida. A metáfora é válida, mas a rigor é "irreal", porque não interessa nem corresponde à geografia de um lugar identificável. Toda a caracterizaçăo da natureza tem a mesma funçāo, em M. A última citação, da p. 352-3 guia o leitor para os olhos de Nhô Augusto Matraga, para a alegria e a descoberta. $\dot{E}$ a liberação dos males passados. A descrição puxa a alegria, expressa em cantigas cantadas por Matraga, que o encaminham para uma palavra (longe), que desperta uma descoberta: "- Adeus, minha gente, que aqui é que mais näo fico, porque a minha vez vai chegar, e eu tenho que estar por ela em outras partes!"z8.

Em $S_{.}^{29}$, as descriçōes valem por si, afora revelarem os preconceitos de Valdomiro Silveira, quando hierarquiza cobras, sapos e passarinhos. "- Não hai nada que mais me doa no coiraçāo do que ver o diabo duma cobra perseguindo a cantiga dos passarinhos! Inda se a coisa fosse ca's gimbuias ou ca's pererecas, vá: que bicho à toa e rúim, ver o sapo, eu não conheço, a nāo ser a própria cobra: mas porém cu'm bicho bonitinho, que 'tá dobrando sentado na arve, sem não fazer dano de espécie argúa. Năo tem jeito, isso nāo tem altura!"30.

Um dos preconceitos é manifestado através da "piedade" sentida pelo passarinho que será comido pela cobra. Para o ser humano carnivoro, trata-se de uma falsa pena. A própria personagem percebe isto e se justifica - mal: aceitaria a morte de um animal morto pelo outro se no lugar do passarinho estivesse um sapo. Mais adiante a personagem-narrador se dá conta deste outro preconceito e se justifica de

26. Idem, ibidem. p. 352-3.

27. Daqui para a frente "A hora e vez de Augusto Matraga" será indicada apenas por $M$.

28. Idem, ibidem. p. 354.

29. "Saluaçăo" passa a ser referido como $S$.

30. SILVEIRA, Valdomiro. Op. cit., p. 65. 
novo, aceitando a morte do bicho feio. Ao opor o bonito ao feio, confirma o preconceito. Outro preconceito é o de linguagem. No trecho, Silveira tenta representar a oralidade, i.e., arremeda a fala do caipira. Ao tentar a reproduçäo fônica dos sons, Silveira mistura formas da escrita e da norma culta desajeitadamente com o dialeto caipira $e$ a forma da oralidade. Usa formas sincopadas ('tá, ca's, cu'm, arve - por árvore, pass'o - por pássaro) indiciadas pela apóstrofe, i.e., ressalta o desvio com respeito à norma culta, que permanece como referência de valor. Quando nāo, Silveira repete o sentido com uma expressão equivalente: "Não tem jeito, / isso nāo tem altura!" "Mansamente, / pé ante pé". Pareceria que a $1^{\underline{2}}$ expressāo é usada como garantia para que se entenda a 2 . Silveira procura registrar a indiferenciaçăo entre le r em argúa e mais adiante em marvadas, fror, mardita. Mas escapam-lhe altura, algure' (por 'algures'). O plural no dialeto caipira é feito no artigo, permanecendo o substantivo (nome) e o verbo sem modificaçāo. Silveira mistura as modalidades de linguagem grafando, por vezes, o plural culto, da escrita (concordando artigo, substantivo $e$ verbo): dos passarinhos; ca's gimbuias ou ca's pererecas; as marvadas escolhem; os coitados 'tāo etc. Isto não é novidade nos estudos lingüísticos. Nos estudos literários também se encareceu o contraste dos registros, mostrando que nesses textos "se nota o choque da passagem da fala culta do narrador, no discurso indireto, para a rusticidade do dialeto caipira, no direto; quando do uso do indireto-livre, os vocábulos da fala cabocla aparecem aspeados ou grifados, acentuando o contraste entre os dois registros" ${ }^{\prime 31}$.

No "choque de passagem", além do contraste entre os diferentes registros, revela-se o "meio conhecimento" do dialeto, que provoca um contraste ainda maior, porque aponta tanto para a diferença de normas gramaticais, como para a irregularidade de conhecimento delas e, pois, para o erro e para o ridículo. E fica parecendo que erradas e ridiculas são as personagens que pretensamente usam este dialeto e que ai estão expostas sob a forma do discurso direto - e nāo o autor de tal inconsistência de uso da linguagem. Esse involuntário preconceito com respeito às personagens e ao mundo natural das narrativas é acompanhado - ou indiciado - pela estagnaçāo e mesmice que Dias ${ }^{32}$ acaba por perceber nas narrativas, sobretudo em relaçāo às descriçōes da natureza.

Portanto, apesar de Dias afirmar o caráter também universal das narrativas de Valdomiro Silveira, reconhece os seus aspectos falhos ou pequenos ${ }^{33}$. O que Dias chama de duplicidade do foco narrativo, vem a ser contradição reducionista,

31. YATSUDA, Enid. O caipira e os outros. In: BOSl, Alfredo (org.). Cultura Brasileira: temas $e$ situaçōes. São Paulo, Ática, 1987. p.103-13.

32. DIAS, Carmen Lydia de Souza. Op. cit.

33. Segundo ela, nota-se uma mistura feita de, por um lado, "brilho e sononidade léxica" e, por outro, "de um grande clima de estagnação e mesmice, que faz o tempo do sertão parecer parado; e o espaço, um vasto mundo esquecido e monótono, em que a natureza está indiferente ao problema humano e onde a figura central o homem, caminha alegre ou triste, tendo sempre horizontes limitados, aspiraçōes curtas, sem consciència exata de si e do seu meio, embora esteja intimamente ligado a ele, voltado para o cotidiano do bairro, que é a porçāo concreta de um 'mundão de Deus', apenas difusamente pressentido." (Idem, ibidem. p. 175). 
como vimos que sucede com a linguagem.

Guimarāes Rosa usa expressões do universo da fala caipira, mas as normas gramaticais sāo as da norma culta. Além disto, nāo há diferença entre o discurso indireto e o direto. E há mais. A atribuiçăo de valor, inteligência, sabedoria, beleza poética ao caipira, faz com que o registro e a descriçăo da natureza local sejam recobertos pelo que de positivo e grande existe nas personagens.

O regionalismo hesita na falta de parâmetros. O pitoresco tende a limitar-se à descriçāo da natureza diferente (da européia) e a açăo humana, quando valorizada, como neste conto de Valdomiro Silveira, é exacerbada em um dos seus aspectos, mas ainda assim perde o sentido social, porque nem sequer se insere em um passado pessoal: năo se integra nem no próprio sujeito, nem numa coletividade. $O$ registro do "erro" de linguagem desqualifica o universo mental presumivel do caboclo, relacionado de forma direta ao universo cultural, econômico e social. A perspectiva de Valdomiro Silveira é, como o descreve Herman Lima e o retoma Dirce Côrtes Riedel ${ }^{34}$, de uma "ingenuidade comovida", e de "uma ternura comunicativa", o que a rigor significa: redução da dimensão humana para sentimentos infantilizados; atribuição de valor simbólico à descriçăo da natureza, apresentada não como espaço para a açăo, mas como a açăo propriamente dita.

A redução da história à história de animais (já que a narrativa se inicia com animais), transforma-os em representaçōes vicariantes do ser humano e a açăo em representaçāo de conflitos, tensōes, afetos humanos, como nas fábulas. Nestas, as personagens costumam ser reduçōes caricatas de vícios ou defeitos - ou virtudes humanos, porém sempre referidos à sociedade. São apresentadas prontas e definitivas, sem que se vislumbre um processo, ou uma mudança espiritual ou psiquica. A sua moral corresponde à moral social, coletiva, cristalizada. No caso de $S$. a história é de medo e fascínio. A cobra fascina (hipnotiza) o gurundi, que ao mesmo tempo tem medo. Aparentemente tem medo da morte. Mas o tema é o do amor. E até a dupla cobra-gurundi representa o casal, macho e fêmea. (É curioso como Valdomiro Silveira fala em gurundi macho enquanto interessa, na relação cobra-gurundi, e passa gurundi para fêmea quando procura um argumento lacrimogêneo-romântico, aceito pela moral burguesa. Está a gurundi, às p. 66 e 67/ ${ }^{35}$. Ora, a simbologia antiga, ancestral, de cobra é de Mal, sexo e símbolo fálico.

Recapitulando: Albino vê a cobra que hipnotiza a gurundi (ou, o falo que fascina a fêmea), fica horrorizado e quer acabar com a cobra. Mas enxerga um casal de aves, que ai não têm a conotação fálica assustadora, da cobra, e por isso acaba salvando a todos. Isto $\dot{e}$, decide manter vivos todos os envolvidos, a saber, a sexualidade. A rigor, o grande gesto é a manutenção do status quo. Chegamos ao tema

34. SILUEIRA, Valdomiro. Salvaçāo. In: Os Caboclos. Introd. critica de Dirce Côrtes Rjedel. 3. ed. Rio de Janeiro, Civilizaçāo Brasileira, 1962.

35. "Aqueles uns nāo se importam c'a sorte da gunundi que 'tá morte nāo morre!' [...] mas a desinfeliz da gurundi é que já tem redada, que 'tá esperando' por ela, e 'tá' mesmo!"). 
de amor e medo, tão bem trabalhado por Mário de Andrade ${ }^{36}$.

Dentre os poemas apresentados por Mário de Andrade está um, de Casimiro de Abreu: "Amor e Medo".
"Tenho medo de mim, de ti, de tudo,
Da luz, da sombra, do silêncio ou vozes,
Das fôlhas sêcas, do chorar das fontes,
Das horas longas a correr velozes.

\begin{abstract}
"Ail si abrasado crepitasse o cedro,
Cedendo ao raio que a tormenta envia,

Diz: - que seria da plantinha humilde

Que à sombra dele tão feliz crescia?" ${ }^{37}$.
\end{abstract}

"Casimiro de Abreu é mestre nesse gênero de poesia graciosa, própria dos assustados familiares, que a gente vive esquecendo que no fundo é bem pouco inocente" ${ }^{\text {"38. }}$.

A construção é metonímica, relacionando inocência a virgindade, santidade a infantilidade, como opostos absolutos do desejo ${ }^{39}$, que - ao contrário da ingenuidade - é perverso, satânico, imoral. A natureza é o melhor palco para a representação desta fábula, como se lề no poema de Fagundes Varela, citado por Mário de Andrade ${ }^{40}$.

A "ingenuidade comovida" de Valdomiro Silveira em verdade termina por caber no que Mário de Andrade diz de Casimiro de Abreu. Valdomiro Silveira se engaja no projeto regionalista, que quer as narrativas coladas à realidade rural, natural, mas tem uma postura que, tanto na linguagem como na moral, acompanha os preconceitos burgueses. A moral burguesa leva ao encobrimento do erotismo, da sensualidade. Silveira revela uma face ingênua, por trás da qual existe o grande segredo. A comoçăo na verdade esconde o ardor do desejo. O ocultamento do erotismo leva a corar. (No conto "Saudades do Natal", do mesmo livro de Valdomiro Silveira, as saudades recalcam a relaçāo amorosa, desviam-na e chegam ao ponto de converter o amor pleno e realizável no presente, em um amor passado e perdido, assentado na melancolia voltada para esse passado sem volta. Como o presente

36. ANDRADE, Mário de. Aspectos da Literatura Brasilelra. 4. ed. São Paulo, Martins/Brasilia, INL, 1972, p. 199-229.

37. Idem, ibidem. p. 200-1.

38. ldem, ibidem. p. 205.

39. Leia-se, por exemplo, o seguinte trecho de poema de Fagundes Varela, "Evangelho nas Selvas":

"Aves de Deus, as virgens e as crianças

Adormecem risonhas, ocultando

Nas asas da inocência as frontes santas." (P. 201).

$40 \mathrm{ln}$ : FAGUNDES VARELA. Juvenilia, apud ANDRADE, Mário de. Op. cit., p. 213-4. 
não consegue ser vivido, explode em pranto, que reprime o medo do erotismo). $O$ processo de substituiçăo - e de sublimaçāo - é tal, que a personagem ser humano de $S$. pareceria ser onipotente, decidindo da vida e da morte. Sua posição com respeito aos outros é de desigualdade: o mundo animal, coletivo, é salvo pelo exemplar (humano) único, que se encontra em situação de salvá-los por ser mais do que apenas um foco narrativo onisciente: é a personagem onisciente e onipotente.

Albino vê e entende tudo o que ocorre no palco da natureza, como um deus. Ao salvar os animais tem um gesto magnânimo, coisa de senhor para com vassalos, ou do Senhor para com os homens.

Salvaçāo para quê, mesmo? Para que o mundo esteja em ordem. Bom e sāo é o mundo. A grandeza do desígnio superior é manter vivos bem e mal, a cobra e os passarinhos, mesmo que uns sejam bonitos (e bons) e os outros feios (e ruins), mantendo o equilibrio universal. Esta sabedoria de Albino eleva-o a um nivel que transcende o mito. O mito contemporaneo, segundo Roland Barthes, tende a considerar a ordem instituída boa, porque natural. Trata-se de um silogismo que gira em torno de seu eixo, afirmando, mostra Barthes, que a ordem instituída - que sendo instituída é fruto de cultura e história - em verdade é natural (e não instituída) - e por isso boa. Ou antes, a ordem estabelecida é boa porque conhecida. Por ser conhecida parece ser racionalmente abarcável. Sua lógica, na medida em que é conhecida, permite ser tratada por normas de comportamento fixas e previstas. Implica estar sob o controle e a responsabilidade da autoridade. É também mais seguro. Tudo o que seja diferente desta ordem é perigoso e ameaçador.

$O$ regionalismo de Valdomiro Silveira pode ser definido pela atraçāo pelo outro, cheia de medo e fascínio pela diferença. A atração pelo medo paralisa a criatura. O homem contempla a cena como um ser superior e năo envolvido, como o seu criador. Como os ingredientes do conto também poderiam fazer parte do universo das lendas indígenas brasileiras, poderíamos acreditar que o regionalismo aproveita essa referência. Nas lendas indigenas os símbolos se referem, por exemplo, à regeneração da terra e da vida, manifestação de esperança e confiança na perpetuação da vida. (Tenho em mente mitos dos índios Tembé do Pará e Maranhäo, recolhidos por Curt Nimuendaju). Em verdade o caboclo da literatura regionalista, estigmatizado, quer o outro, o europeu, o civilizado e urbano, ao mesmo tempo que nāo consegue deixar de ser ele próprio também. Valdomiro Silveira, ao manter os dois principios no mundo natural (vida e morte; bem e mal; amor e medo) estabelece um equilibrio instável de forças e tensōes, ao mesmo tempo que manifesta a sua necessidade de gerenciá-las.

Na construçăo da narrativa, a falta de coragem diante dos sentimentos plenos, a moral camufladora timorata, leva à indefiniçäo das formas. $S$. nāo participa das funçōes do mito (que naturaliza), nem das funçōes de um caso, ou de uma história de vida de santos - e nem mesmo de uma fábula, já que nem tem coragem de explicitar a moral instituida, que culminaria as fábulas clássicas. Pendurado entre formas, o conto cumpre mal aquilo que para as formas simples é fundamental: o holismo, que atribui sentido à vida e ao mundo. Porque o sentido final do conto é a manutençäo do status quo. $O$ que é pouco. As formas simples servem para apre- 
sentar uma resposta ao mundo, tentando, sempre, explicá-lo. Os contos de Valdomiro Silveira procuram menos explicar o mundo que apresentar um registro provisório e fugaz do que seria a realidade. Por isso correspondem antes a uma cena do cotidiano, fragmentária, do que ao sentido de uma vida.

"A hora e vez de Augusto Matraga" insere-se em um livro chamado Sagarana (isto é, à maneira da saga), o que permite pensá-lo como feito à maneira das narrativas orais, como o são as sagas. A oralidade, no conto, é entendida como caracteristica de valor, tanto para a caracterizaçāo das personagens, como para criar efeitos poéticos. Descrever a natureza näo é um programa: decorre do aproveitamento da poesia do mundo sertanejo. A meu ver esta positividade imprimida na construção da narrativa decorre também do aproveitamento de referências textuais comuns aos dois universos, o da oralidade e o da escrita.

Dentre as narrativas orais, aproximam-se da forma da saga os relatos da literatura de cordel sobre a vida de cangaceiros, como Lampiäo. Desses diz Câmara Cascudo ${ }^{41}$ :

"A gesta é uma poesia de ação, de luta e de movimento. Não há a sensação da paisagem, da natureza e do cenário. Verso descrevendo esses elementos denuncia inteligência semiletrada e nunca a produçāo se destina aos lábios dos cantadores. Os cangaceiros sāo as figuras anormais que reúnem predicados simpáticos ao sertão. A coragem, a tenacidade, a inteligência, a força, a resistência [...]. Os cangaceiros são a horda brava e rude, cavalania frenética e primitiva até no processo de matar [...]. $\mathrm{O}$ sertāo guarda a lembrança dessas dinastias de facínoras, heróis e bandidos [...]. E como o sertanejo deduz de toda luta um aspecto moral, um direito preterido, um patrimônio violado, os poetas populares dizem que é o desrespeito às minorias, que nunca se fizeram sentir ante a arbitranedade dos governadores, um dos motivos da eterna guerra [...]".

"E os cangaceiros convencem-se de seu papel de justiça social, defendendo pobres e tomando dinheiro aos ricos. Lampião confessa:

"Porém antes de eu ser preso,
hei de mostrar o que faço
dar surra em cabra ruim
roubar de quem for ricaço.
Só consinto em me pegar
no dia em que alguém pisar
em cima do meu cangaço..." 42 .

Guimarāes Rosa reflete aspectos da estrutura e função da forma simples 41. CASCUDO, Luis da Càmara. Vaqueiros e cantadores. Belo Horizonte, Itatiaia/São Paulo, Edusp, 1984.

42. Idem, ibldem. p. 164-5. 
saga, tendo como referência provável as sagas nordestinas. Por outro lado, ele procurou discernir bem os aspectos letrados de suas narrativas. A açäo, como nas gestas, tem importância primordial. A personagem principal năo segue apenas a sua existência, levado de roldão pela roda da vida. Matraga se empenha, coronel ou santo, a ser o protagonista dos acontecimentos. Nāo contempla, nem se cala, conformado. Sua imprudência mandante e machista vira decisāo e luta pela justiça. A coragem é a marca do herói.

As sagas nordestinas lidam com dois conceitos de justiça, verdade, coragem: um, da ótica do cangaceiro, injustiçado, oprimido e outra, da perspectiva do poder instituido:

\author{
"Assim como sucedeu \\ ao grande António Silvino, \\ sucedeu da mesma forma \\ com Lampeāo Virgolino, \\ que abraçou o cangaço \\ forçado pelo destino" \\ $[\ldots]$ \\ "Porque no ano de Vinte \\ seu Pai fora assassinado \\ da rua da Mata Grande \\ duas léguas arredado... \\ Sendo a força de Policia \\ Autora deste atentado...
}

"Lampeão desde esse dia jurou vingar-se também, dizendo: fol inimigo, mato, nāo pergunto a quem...

Só respeito neste mundo

Padre Cisso e mais ninguém!..."43.

O acontecimento histórico de Lampiāo e cangaceiros transforma-se em saga na medida em que a luta é cristalizada em torno de um herói com altas virtudes, que luta em nome dos interesses de uma familia: propriedade, vingança do sangue derramado no sangue de um familiar do criminoso (ou culpado), fidelidade fraternal, ciúme, rixas entre mulheres, concubinato. No caso brasileiro, o clä é substituído

43. Idem, ibidem. p. 162. 
pelo grupo solidário, fraterno, neste sentido, familiar, como requer a saga. Matraga tem primeiro o perfil do coroneläo, para logo a seguir converter-se no injustiçado que precisa vingar a perda da propriedade e do poder, da mulher e da honra, da filha $e$ da família. Torna-se um despossuido, que se junta a outros despossuídos. Desta forma, Rosa tematiza justiça e opressão, contraposta à ótica do poder instituido, representado genialmente pela mesma personagem. "O Mal sou eu. O Outro sou eu..." poderia dizer Matraga.

$M$. nāo registra um acontecimento histórico: representa-o, mostrando a troca de mäos do poder e da propriedade, frágeis em uma terra sem leis, normas, justiça. $O$ cangaceiro de $M$. não é o herói principal da narrativa, apesar de se tornar, afinal, um herói também. Joāozinho Bem-Bem quer vingar o sangue derramado de um cangaceiro de seu grupo através do sangue de um familiar do criminoso. A fidelidade fraternal leva Joãozinho Bem-Bem e Nhô Augusto Matraga à luta corporal pessoal. A luta entre os dois amigos que circunstancialmente se tornam rivais reúne os inimigos, de início na luta, mas depois no respeito ao valor mútuo, na estima, assim como no respeito póstumo exigido por Matraga para o corpo de Bem-Bem. Quer proximar os grupos inimigos, em nome de instituiçöes diferentes. Joăozinho Bem-Bem representa a velha ordem, ou a ordem do presente. Nhô Augusto, após a sua conversão, luta por uma nova ordem que elimina a inimizade, reunindo os contrários. Torna-se o paladino da justiça - em nome de Deus. Como um recém convertido.

A luta suspende este sentido de justiça, instaurando outro, divino. Nāo a justiça instituída pelo poder e nomeada de divina, mas a outra, transcendente mesmo. Reverte-se o mundo - às avessas - da saga nordestina. Vingança não será mais chamada de justiça. Traição da mulher ao marido não será nem infidelidade para com o marido, nem fidelidade desta ao amante, mas apenas a relaçăo amorosa possivel, fundada na realidade; a violência não será justificada por si só; é preciso luta para garantir a reversāo do arbítrio. Isto é possivel por tratar-se de história inventada: é manifestação de desejo. Mas segue a tradição de relato da literatura de cordel. Esta verbaliza o problema da verdade em si, garantindo a honestidade do narrador. Acaba fazendo referências metalingüisticas, que podem desembocar num conhecimento tăo preclaro, que chegam até o inconsciente:

\author{
"Agora caro leitor \\ me ouça com atenção \\ vou contar uma estória \\ de causar admiraçăo \\ já que vocẻ não ouviu \\ uma com mais precisāo" 4 .
}

44. "O pássaro encantado da gruta do Ubajara". In: BATISTA, Abraz̉o. Literatura de Cordel: antologia. São Paulo, Ed. Global; s.d., v. 2, p. 13. 
"Agora que eu andei
pelas florestas do além
penetrei no inconsciente
intimo que cada um tem,
sinto-me autorizado
para escrever o que vem"45.
"A verdade eu vou dizer
Sem andar em contra-mão
Em mil oitocentos e noventa e quatro
Sendo no mès de São Joāo
Na fazenda terra vermelha
Na mesma nascia Lampiāo.

A verdade eu revelo

Afirmando com exatidāo

Se houver necessidade

Eu provo em gravaçăo

Que ele foi almocreve

Ao lado de cada irmão"46.

As sagas do cordel brasileiro insistem em que o conhecimento é possivel a partir de acontecimento vivenciado pelo narrador e registrado pela visão, memória e palavra, de um despossuido, diferente de outras versões. Guimarães Rosa encontra, na versão do conto conhecida a partir de 1946, uma outra solução. Lemos: " $E$ assim se passaram pelo menos seis ou seis anos e meio, direitinho deste jeito, sem tirar e nem por, sem mentira nenhuma, porque esta aqui é uma estória inventada, $e$ näo é um caso acontecido, năo senhor"47.

A história precisa ser inventada para consertar o mundo às avessas vivido pelo coronel, seus capangas e o mundo da jagunçagem... e para dar voz ao universo do desejo de Matraga e verossimilhança ao milagre da conversāo e aos caminhos tortos da vontade divina. Também precisa ser construída de modo diferente da forma tradicional: as personagens nāo devem ser maniqueizadas. Matraga nāo é apenas mal, mesmo no início da narrativa: era para ser padre; respeita e não respeita a igreja; humilha a Sariema, preservando-a para o capiau. Joãozinho Bem-Bem tem bem no nome, mesmo sendo cangaceiro e representando a ordem, justica, coragem do mundo às avessas, isto é, contrário ao poder instituido, que atribui a

45. "Luta de um homem com um lobisomem". Idem, ibldem. p. 103.

46. CRISTÓVĀO, José Severino. Toda a verdade sobre lampiäo e seus cangaceiros. s.n.t.

47. ROSA, Joäo Guimaräes. Op. cit., p. 338. 
maldade ao mundo às avessas.

A construçāo das personagens das narrativas sobre a vida dos grandes cangaceiros assemelha-se às histórias de santos. Como Antonio Silvino, Lampião é tido pelos cantadores como um infeliz, obrigado a viver errante por ter vingado a morte de seu pai. Pareceria que os grandes cangaceiros têm uma vida de condenados, como o Judeu Errante, punido por não receber a Cristo e condenado a não morrer à vista de todos, vivendo errante eterna e incessantemente. Como o Judeu Errante, o cangaceiro é uma espécie de anti-legendánio, de anti-Cristo ${ }^{48}$. (Aliás, Matraga penitente faz um percurso errante, inicialmente, até se fixar para expurgar-se).

O cangaceiro também participa de características do homem virtuoso: seus feitos são extraordinários e até certo ponto milagrosos, tanto assim que recebe o aval de Padre Cícero. É um santo às avessas em dois sentidos:

- transforma suas virtudes em poder, utilizado em benefício de terceiros, porém em vida - e nāo depois da morte;

- merece celebraçōes e culto em vida - e nāo depois de morto, como o santo.

A construçāo da história nas narrativas de cordel é imitável, ainda que sua

48. O cangaceiro, enquanto anti-Cristo, tem os poderes do anjo Satā, como se lè nos trechos que seguem:

"Satā rogou a Lampiāo

Prá sair do seu Interno

Lampiāo foi camarada

Foi prá porta do Céu eterno

Mas São Pedro se benzeu

Lhe pediu prá sair temo

"Seu padrinho, Padre Cicero

Foi lá seu advogado

Mas não pode defendê-lo

Indo contra os jurados

Juiz Deus por maioria

[...]

"Em Pernambuco já fez

Recém nascido falar

Pedir armas, pinga e fumo

Mandar mãe praquele lugar

Fazer proezas que só Cão

E outros trens d'arrupiar".

(MAXADO, Nordestino. A alma de Lampiōo faz misérias no Nordeste. s.n.t., p. 5-6). 
vida seja relatada como sendo histórica; é feita de fragmentos da realidade histórica, embebidos em valor de imitabilidade, que caracteriza as histórias de santos. Apanha a multiplicidade e diversidade do evento, cristalizando-o na figuraçāo de um conceito único. Os guerreiros da literatura de cordel (Lampiāo, Antonio Silvino, sobretudo a donzela Teodora ou outros) têm sede e orgulho de conhecimentos e saber, i.e., querem penetrar todos os segredos do mundo. Para alcançar o que almejam afastam-se da humildade cristã e da sujeiçāo aos desígnios divinos, fazendo um pacto com o Diabo. Nos santos, a bondade ativa sobrevive à personagem. No guerreiro- cangaceiro, a maldade ativa também sobrevive, tomando corpo em outros jagunços, ou no lobisomem e outros seres.

Em estudo sobre M., Walnice Nogueira Galvăo ${ }^{49}$ analisa a hagiografia relacionada ao conto, especificamente à marca em Matraga (o triângulo inscrito na circunferência), à sua história pia e à freqüência de trios e trindades.

"A narrativa de Guimarāes Rosa é uma histónia pia, e como uma leitura pia deve ser lida, com todos os seus prodigios, presságios e simbologia. Sendo tamanha a importância do emblema de Matraga, seria de se esperar que a narrativa de sua "vida" seja comandada por um compasso ao mesmo tempo ternáno e circular. Dado que a composiçāo do conto remete os eventos a um tempo mítico, que nāo interessa em datar, a circularidade se expōe no já acontecido, no per-feito. Começa com o nome de Matraga [...]

"Assim é que a personagem tem três nomes: Matraga, Augusto Estêves e Nhō Augusto. O primeiro é o nome mítico, o segundo o nome social, o terceiro o nome individual. O primeiro de santo; o segundo, de coronelão fazendeiro, rico e prepotente; o terceiro, do individuo em sua demanda" 50 .

"Matraga também vive em trios [...]"51.

"A trilogia mítica dos ritos de iniciação - morte, renascimento e vida - reaparece aqui em sua forma cristă, de pecado, penitência e redençăo, ou inferno, purgatório $e$ céu. A uma vida de pecado se sucede uma morte aparente, seguida por uma ressurreiçāo para uma nova vida, prefiguraçāo da passagem da vida terrena para a vida eterna através da morte do corpo e salvação da alma. A quase-morte é uma espécie de aviso e última oportunidade ${ }^{252}$.

Nogueira Galvāo escolhe duas histórias da Flos Sanctorum, para exemplificar como $M$. não destoaria de seu corpo de narrativas ${ }^{53}$, concluindo pela "mistura de sublimitas e humilitas na arte cristã popular medieval em contraste com a arte cortesā, que se encontra tanto nas peças teatrais como nos escritos de e sobre São

49. GALVĀO, Walnice Nogueira. Matraga, sua marca. In: Mitológica Rosiana. São Paulo, Ática, 1978, p. 41-74.

50. Idem, ibidem. p. 61-2.

51. Idem, Ibidem. p. 63.

52. Idem, ibidem. p. 63.

53. Idem, ibidem. p. 67-8. 
Francisco de Assis. [...]"54, perguntando-se, a partir dessa conclusāo, se poderia ocorrer "nesses textos, tal como no Matraga, o fluir de uma corrente de cristianismo popular, em que a divindade, longe de ser o Deus otiosus de que fala Mircéa Eliade, seja ao contrário presente e atuante, e o sagrado nāo tenha limites demarcados com relação à vida cotidiana?"5s.

A presença viva do sagrado sem "limites demarcados com relaçăo à vida cotidiana" existe em todos os textos de Rosa. $M$. aproveita mais de perto a estrutura das hagiografias.

Nas histórias de santos distingue-se a ruindade ativa da ruindade passiva, assim como a virtude ativa da virtude passiva. A ruindade ativa é distinguida por ato manifesto, condenável e punivel. A virtude ativa corresponde a uma norma superior, concretizada, confirmada e objetivada com a morte. A história de santos parte de algumas premissas:

1 - A história de santo trata de homem virtuoso, cuja virtude fica patente pelo milagre.

Matraga não é, mas torna-se virtuoso. O desejo da avó de destiná-lo para a Igreja aparece como detalhe, como curiosidade. É significativo que afinal dê certo mesmo que em vez de padre ele vire santo ${ }^{56}$.

O que acontece com Matraga, no conto, é explicitamente obra de Deus:

"- Pois eu gostava era que viessem todos juntos para o meu rancho...

- Não será abuso, mano velho?

- É näo... É de coração.

- Pois então, vamos, que Deus lhe pagará! ${ }^{57}$.

Guimaräes Rosa aproveita, sim, a forma da história de vida de santo, mas inverte alguns sinais, de modo a incluir transformação, ascese, redenção do homem.

2 - A história da vida de santo só é contada depois de sua morte.

Em $M$. também, o que é confirmado pelo título do conto, que só pode ser pensado como contado depois de sua morte, ainda que a partir de uma perspectiva cronológica linear, que finda na e com a morte. Como o conto é longo $e$ a realização de Matraga só se dá no fim, o leitor năo sabe imediatamente que o acontecimento já aconteceu. A perspectiva recebida é a apontada mais atrás.

54. Idem, ibidem. p. 68 .

55. Idem, ibidem. p. 71-2.

56. "Quem criou Nhô Augusto foi a avó... Queria o menino p'ra padre... Rezar, rezar, o tempo todo, santimônia e ladainha..." (ROSA, Joāo Guimaräes. Op. cil., p. 331); "Nāo deixem este santo morrer assim." (Idem, ibidem. p. 364).

57. Idem, Ibidem. p. 345 . 
3- Nas histórias de santos o milagre se torna independente do milagreiro, a fim de confirmar a virtude e o milagre.

Não é o caso de Matraga.

4 - Só depois da independização entre milagre e milagreiro existe novo passo na composição da história (a re-uniäo entre virtude e virtuoso), de modo a construir o santo.

Em $M$. o milagre se independiza, a fim de imergir o milagreiro no safado comum, ser humano que se lembra de mulher e filha antes de morrer. A recomposição da história se dá graças à referência às tradiçōes culturais brasileiras. celeste.

5 - Uma vez santo, há celebração de festas da Igreja e culto da personalidade

O tratamento reservado à personagem Matraga, afinal nem santificado, nem herói épico, só pode ser entendido quando recolocado no contexto das tradiçōes brasileiras, incluindo-se a ordem e poder instituidos.

6 - A virtude transforma-se em poder, graças às reliquias.

Não aparecem reliquias na história. Matraga morre a céu aberto, nāo aceita ser levado para dentro de recinto fechado e também nāo aceita que Joãozinho Bem-Bem seja tratado como o representante da ruindade ativa. $O$ milagre, propriamente, é um milagre social, cultural e näo tanto factual. (Normalmente o milagre é ou de salvação da vida, ou de órgãos - portanto, corpo - de um necessitado, ou bem a transformação de um objeto em outro, ou a multiplicaçăo de uma coisa: um peixe converte-se em milhares de peixes; pães são transformados em flores etc. Afinal, em $M$., em vez de salvação há substituiçäo de mortos $e$ - com isso - uma outra concepção de justiça. la morrer uma só pessoa, um dos filhos do velho pai do jovem assassino do Juruminho e acabam mortendo duas pessoas: Bem-Bem e Matraga ${ }^{58}$ ).

7 - Utilizaçăo do poder em benefício de terceiros.

Em $M$., sendo o milagre um milagre social, automaticamente rende beneficios a uma coletividade, mas nāo a terceiros individuáveis.

A construçăo da ascese de Matraga consiste fundamentalmente em aprender as virtudes teologais: fé, esperança e caridade. As virtudes morais vêm por acréscimo: justiça, prudência, estoicismo, temperança. São nitidamente secundárias para o religioso, mas muito pelo contrário para Nhô Augusto, cuja ascese passa justamente pelo acerto no campo das virtudes morais.

O espaço da história de santos forma uma comunidade baseada em solidariedade reciproca. No ritual religioso isto corresponde ao ano litúrgico. Para o caipira, também, dando sentido também à sua própria vida.

A história de santos apresenta uma vida como modelo de virtude ou maldade consubstanciada. Não interessa a continuidade da existência humana, mas aqueles

58. "Três dos cabras correram, porque outros três estavam mortos, ou quase, ou fingindo." Idem, ibidem. p. 362. 
instantes em que se dá a objetivação.

O aproveitamento da estrutura das histórias pias vai só até certo ponto: Matraga não será tratado como santo, propriamente, a fim de não repetir uma história de assimetrias pessoais, sociais, culturais, politicas garantidas mesmo e também pelas vidas dos santos.

Como o conto de Rosa apresenta aprendizagem (de Matraga) e ensinamento (para os leitores), pareceria ser uma parábola. Nas parábolas Erich Auerbach localizà o que chamou de "figural".

"A interpretaçāo figural estabelece uma relaçäo entre dois acontecimentos ou duas pessoas, na qual um deles não só se significa a si mesmo, mas também ao outro $e$ este último compreende ou completa o outro. Ambos os pólos da figura estăo separados temporalmente, mas estão, também, como acontecimentos ou figuras reais, dentro do tempo. Ambos estāo contidos no fluxo conrente que é a vida histórica, $e$ somente a sua compreensão, o intellectus spiritualis da sua relação é um ato mental"59.

$M$. näo pode ser lido como parábola, no sentido de Auerbach, porque a história de Matraga não pode ser referida apenas à história de Cristo. $\mathrm{O}$ conto precisa ser referido às sagas e às histórias de santos e ao regionalismo, à imagem de caipira brasileiro, à sua representação como personagem e, enquanto linguagem, às relaçōes de poder na sociedade agrária e rural brasileira e à sociedade em geral. Já porque o sentido de destino depende da atitude das pessoas-personagens impregnadas pelo esoterismo. (Para os que comungam com o Circulo Esotérico da Comunhão do Pensamento, lido e relido diversas vezes por Guimarães Rosa ${ }^{60}$, o sentido de destino é determinado pela vontade pessoal $e$ visão positiva da açăo humana; a ponto de criar e manter o lema "Hei de vencer").

As religiōes e mitologias populares vivas tèm algo das religiōes dos mistérios e soteriológicas, portanto algo de irracional, apesar de o esoterismo elaborar racionalmente o seu ecletismo. (É uma mistura de elementos do cristianismo, do judaísmo, do hinduismo como passos, ou símbolos, ou passagens possiveis e necessárias para chegar ao Karma. Para chegar a ele são usados, pelos esoteristas, meios práticos de vida - os pensamentos positivos - que ao mesmo tempo servirāo para que o individuo que os pratica tenha sucesso na vida cotidiana. Estas mediaçöes seriam ilicitas para o real hinduista, porque simplificadoras. Rebaixam o panteão divino, na ilusão de uma pretensa ascese. Filosofia do mistério, o adentramento na doutrina consiste no que, para o yogui, se consegue adentrando em si mesmo. A doutrina da Comunhão do Pensamento, como via de acesso para a transcendência, dessacraliza relativamente o mundo, por convertê-lo - material e contingente - em um dos pon-

59. AUERBACH, Erich. Mimesis: a representaçāo da realidade na literatura ocidental. Trad. George Bernard Sperber. Sāo Paulo, Perspectiva, 1971. p. 62-3.

60. Cf. FRANKL SPERBER, Suzi. Caos e Cosmos: leituras de Guimarāes Rosa. Sảo Paulo, Duas Cidades, 1976. 
tos de ascese e domínio da transcendência).

O criatural cristão do conto é relacionável à exemplaridade e ao cunho de verdade revelada das parábolas evangélicas, já que a verdade revelada deve sua força de persuasāo ao presente, à presença viva de Cristo. "Matraga", contudo, nāo usa formas populares semelhantes a ditados, como em "O Burrinho Pedrês", aprimorando o sentido criatural da personagem Matraga. O relato năo é univoco como uma parábola, que apenas revela. O espaço nāo é, apenas: abre-se e se renova, numa abertura maior, paralela ao desenvolvimento psicológico-religioso:

"Até que, pouco a pouco, devaganinho, imperceptivel, alguma cousa pegou a querer voltar para ele, a crescer-lhe do fundo para fora, sorrateira como a chegada do tempo das águas, que vinha vindo paralela: com o calor dos dias aumentando, e os dias cada vez maiores, e o joão-de-barro construindo casa nova, e as sementinhas, que hibernavam na poeira, esperando na poeira, em misteriosas incubaçöes"61.

Uma paráfrase do Novo Testamento detectável em "A hora e vez de Augusto Matraga" faria parecer que o conto fosse alegórico, seguindo de perto os Evangelhos. O padre que conversa com Matraga termina por propor-lhe uma jaculatória: "[...] Peça a Deus assim, com esta jaculatória: Jesus, manso e humilde de coraçāo,. fazei meu coração semelhante ao vosso..." ${ }^{\text {"62. }}$. räes Rosa:

A jaculatória lembra de perto trecho dos Evangelhos sublinhado por Guima-

"Llevad mi yugo sobre vosotros $y$ aprended de mi, que soy manso y humilde de corazón; $y$ hallaréis descanso para vuestras almas. Porque mi yugo es fácil e ligera mi carga"63.

O realismo ontológico de $M$. pertence ainda ao domínio do logos por sua força de verdade, de autenticidade das narrativas; do mesmo modo, a necessidade $e$ a ingenuidade do realismo espiritual dos restantes contos de Sagarana. Os momentos que tendem para a naturalização sāo insuficientes para que todo o relato se naturalize, mitificando-se. Já o desenvolvimento pelo qual o que é mal, medo, ódio, vaidade, inveja, orgulho é nuim - portanto feio - constata inversa e antinomicamente que o que é bom é bonito. E apresenta uma estrutura mais complexa. Os sentimentos negativos apontados săo decorrentes da razăo, do pensamento, das normas $e$ leis (racionais) instituidas. Portanto, o pensamento lógico - logos - parece mostrar- se negativo. Ou seja, em meio a esta obra, em que, em seu conjunto ainda se mantêm as características de logos, surge uma abertura para o irracionalismo ainda não desenvolvida, porém.

$M$. corresponde tanto a anseios populares de salvação (prosaicamente, salvação econômica e social; e espiritualmente, de salvaçāo por iniciação, ascese e, so-

61. ROSA, Joāo Guimaräes. Op. cit., p. 342.

62. Idem, ibidem. p. 336.

63. Novo Testamento, S. Mateus, 11: 29-30, apud.: SPERBER, Suri Frankl. Op. cit., p. 45. 
bretudo, perdão divino) por sua forma, pela linguagem, pela beleza poética do texto, que a expressāo do título foi incorporada à fala brasileira. "A hora e vez" condensa com felicidade um complexo de situações contextuais e textuais. Aglutina - em torno do tema da redenção pessoal, da recuperação da identidade e até mesmo do direito à realização pessoal - os conflitos e dificuldades existenciais - e espirituais - da personagem: busca da transcendência, representada pela caminhada e passagem, que simbolizam a purificação e a iniciação a uma verdade revelada. São temas presentes no que não é: nem passadismo, nem aristocratismo, nem grandiloqüuência, ou erudiçāo, ou intimismo. Num momento (entre 1937 e 1946) em que uma das caracteristicas da literatura brasileira é a tensão - entre passado e futuro; entre dramas coletivos e individuais; entre tema e linguagem - Guimarães Rosa não recorre a um tema meramente rústico ou pitoresco, não dicotomiza, nacionalista, dois lados do que seria o Brasil (urbano, industrial e litorâneo por um lado e nural e interiorano, por outro), opondo o culto (= urbano) a inculto (= nural). Cultura, conhecimento, luta, transcendência, valem por si, pelo que săo, livres de rótulos e estigmas. Dá-se, apenas que as personagens vivem no que conhecemos como o Brasil nural, mas que é fundamentalmente um espaço que se abre e transforma em cosmos misteriosamente organizado por forças superiores, no qual se expande e evolui a personagem. Matraga entra pelo sertão mais longínquo como criminoso fugido, a fim de cumprir uma penitência que o inicia no mundo do trabalho não remunerado $e$ em um sistema de troca. Sua apatia e seu excesso diante da vida, vividos na maior contradiçāo, sua arrogância, são corrigidos quando perde o poder - sobre a mulher e filha; sobre suas posses e seus jagunços; sobre seu proprio corpo. Este primeiro momento é apresentado através de cenas que simbolizam a ignorância e a escuridão:

\section{1. do Bem e do Mal \\ 2. de Deus e do Diabo \\ 3. do abuso e excesso \\ 4. da possibilidade de libertação}

O segundo momento, o da punição, da tortura, do sofrimento, é tão pesado, tāo terrivel que substitui o sentimento de culpa (apenas negativo), pelo sentimento de necessidade (vital) de restauração, possivel graças a uma longa espera e funda confiança que se realiza no terceiro momento, deslumbrante de luzes, sons e cores.

Matraga vive um desejo de superaçăo que corrige sua fragilidade de formaçăo, de desenvolvimento, revalorizando a cultura popular, entendida $e$ apreendida por Rosa, como fulcro de um pensamento social antes do tempo. Em outras palavras: Rosa constrói uma personagem com as características do dominador: rico proprietário de terras, mandante poderoso, "dono da cidade", cuja identidade pessoal foi recoberta pela funçāo colonizadora-coronelesca. $O$ ponto de contradiçāo de sua formaçāo é o ensino religioso, inculcado, também, apenas formalmente, ritualisticamente pela avó. Sua identidade pessoal é redefinida na medida em que morre para as funçöes anteriores e renasce para novas funçöes, estas engajadas com o povo - o seu povo - os dominados. Não há discursos de tomada de consciência ideológica. A conscientizaçăo passa pelo próprio corpo, pelo individuo, num 
movimento de dentro para fora, e não inverso. Em 1946, imediatamente depois da Segunda Guerra Mundial, em que as questōes políticas candentes são as ideológicas, num momento em que o Brasil ainda tem o seu ditador - populista - em que a tendência da literatura brasileira tinha sido vazada na forma neo-realista e se pensava o coletivo a partir de uma perspectiva do que corresponderia ao que definiu Arnaldo Jabor ${ }^{64}$ (sobre os tempos da ditadura militar no Brasil) como sendo "nosso compacto esquematismo, que era ungido pelo santo óleo da "utilidade pública", ainda nāo havia condiçōes para se entender esta dimensāo de Rosa, sobretudo expressa como foi, através da busca de realizaçāo encarnada por uma identidade que procura definir-se, redefinir-se, manifestar-se, e para isto precisa que esta identidade lhe seja também socialmente atribuida, transformada, reconhecida, mantida ${ }^{65}$.

Vale insistir numa pergunta: por que Rosa caracteriza a narrativa como sendo ficçāo pura, invenção e não acontecimento, como nas parábolas, ou no Velho Testamento, ou nas sagas, ou na literatura de cordel? Afinal, ele mudou o teor primitivo:

"E assim se passaram pelo menos seis anos e meio, direitinho desse jeito, sem tirar e nem pôr, sem mentira nenhuma, porque esta năo é uma história, mas sim um caso-acontecido, sim senhor" $(1937)^{66}$.

Compare-se com:

"E assim se passaram pelo menos seis ou seis anos e meio, direitinho deste jeito, sem tirar e nem pôr, sem mentira nenhuma, porque esta aqui é uma estória inventada, e nặo um caso acontecido, nāo senhor" (1946) ${ }^{67}$.

A necessidade da "invençāo", do reconhecimento de que o texto é inventado e não real - caso acontecido - serve para atribuir sentido a uma vida inteira, relacionada a uma coletividade com suas normas e costumes. Resgata da fragmentação a apreensão de sentido da vida que nos sobra no cotidiano, dando um sentido de totalidade à vida humana - pessoal e social - resgatadas, ambas, pela dimensão religiosa. A pulverizaçăo do instante é resgatada, tal como a própria vida espiritual de Matraga. (Lembremos que $S$. registra um instante que, sem sentido holístico, fica pobre). A invenção também serve para explicar o caráter especial da religiosidade do conto, não esgotável pela referência cristā. Já dei indicações sobre o assunto em estudo contido em livro anterior ${ }^{68}$. Rosa leu, conservou e deu valor, até 1937, pelo que deu para reconstituir da biblioteca-espólio, sobretudo o livro Primeira Série de

64. JABOR, Amaldo. Folha de S. Paulo, Sào Paulo, 24 nov. 1992, Ilustrada, cad. 4, p. 3.

65. Năo se pode ser hurnano por si, por representaçăo própria: os valores, significaçōes, papéis que me atribuo necessitam de legitimidade social, de confirmaçäo por parte de meus semelhantes. Pode-se dizer que é em virtude de definiçōes que existem indivituo e sociedade. Dentro dessa ótica, é fácil entender que o processo de identificaçāo é um processo de construçāo de imagem.

66. "A opportunidade de Matraga". In: Sezōo (manuscrito do Arquivo Joāo Guimarāes Rosa/IEB).

67. "A hora e vez de Augusto Matraga". In: Sagarana. Rio de Janeiro, Universal, 1946.

68. SPERBER, Suzi FrankJ. Op. cit. 
Instruçöes ${ }^{69}$, afora o Novo Testamento. Esta doutrina tem em comum com a umbanda $e$ a doutrina nagô vigente no Brasil, o fato de serem correntes, aceitas pela população em geral, apesar de dizer-se cristā e católica. A doutrina nagô não é compreendida a não ser na medida em que é vivida e dramatizada de uma maneira ativa. Transmissão pessoal e dinâmica são características especificas do sistema nagô. Como em $M$., o mundo é visto, pelos cultos nagô, ou pela umbanda, como sendo solidário, uno e total. A palavra proferida pelo crente na doutrina nagô é viva - e oral. A oralidade é condição sine qua non da soteriologia nagô, forma única de guardar segredo do mistério religioso. Em M., o relato, por apresentar-se como inventado, representa palavra viva, proferida pelo autor-narrador, palavra com voz e corpo, já que confessa e expressa. $\dot{E}$ um relato com sopro e hálito, dinâmico porque nāo representa meramente a vida de um santo, mas um processo de iniciação e ascese, totalizador e harmonizador das forças opostas no mundo. Para caracterizar bem isto, diferentemente de uma acepção da doutrina judaico-cristā, Rosa- Matraga elimina a culpa - o crime e o castigo, justamente no Tombador (Tombador). Por isto introduz nova ordem no mundo masculino: a fraternidade dos opostos; e nova ordem no mundo feminino da mulher e da filha, onde năo entram honra, vingança, necessidade de perdäo:

do:

“Daí, mais, olhou, procurando Joāo Lomba, e disse, agora sussurrado, sumi-

“-Pöe a benção na minha filha... seja lá onde for que ela esteja... E, "Dionóra... Fala com a Dionóra que está tudo em ordem!

"Depois morreu"70.

"De tudo resta um pouco"... Do regionalismo, resta encarecer que além da diferença entre Valdomiro Silveira e Rosa, é notável verificar que Rosa consegue representar o caipira como homem de primeira categoria - e não simplório e limitado, como costumou acontecer na produçäo regionalista e especificamente no conto analisado de Valdomiro Silveira. Das sagas e histórias pias, resta mostrar como se revela mais produtiva a análise do conto a partir da perspectiva de formas da oralidade, do que apenas de um elenco do que se tem como características de linguagem da oralidade. Estas últimas (repetiçōes, aliterações, onomatopéias, jogos de palavras, rimas, paralelismos, acumulaçāo, sinonímia, comparaçōes, riqueza de imagens, jogos fônicos, aumentativos, diminutivos, climax, explicaçöes sob a forma de apostos) săo em verdade componentes da retórica e tăo incorporadas à escrita que dificilmente se poderá falar de ovo ou galinha. Já as formas provenientes da oralidade, estas sim, permanecem na cultura dos povos mais próximos do agrafismo e foram aproveitadas de diferentes modos ao longo da história literária de todos os tempos

69. PRIMEIRA série de instruçōes. São Paulo, Circulo Esotérico da Comunhāo do Pensamento - Tod- Hé-Van-Hé 1917. Curso de Iniciaçāo Esotérica. 5. ed., cor. e aum. São Paulo, O Pensamento, 1933.

70. ROSA, Joāo Guimarāes. Op. cit., p. 365. 
e podem, pois, constituir aspecto útil para a reflexão e análise literária. Quanto às formas simples - que em $M$. aparecem misturadas e modificadas - elas conseguem atribuir forma e sentido à série literária e à série social - reunindo-as em novas constelaçöes de sentido. Atualizam, nesta mescla, o universal e genérico, e o singular e histórico, permanecendo como virtualidades que podem realizar-se ou não em dado momento histórico ou estágio social, mas que permanecem como referência para o lejtor e contribuem no caráter universalizante da obra. Finalmente, a oralidade imprimida por Rosa em sua obra, contos e romance, novelas e poemas inseridos em seus contos, năo representam apenas recurso astuto de ruptura e renovaçăo da forma $e$ linguagem. Bem mais profundo e significativo é o fato de esta oralidade corresponder ao recurso manutensor do segredo religioso, do mistério da gnose, existente na tradição cultural negra no Brasil.

\title{
LOVE, FEAR, AND SALVATION. APPROACHES BETWEEN VALDOMIRO SILVEIRA AND JOĀO GUIMARÄES ROSA
}

\begin{abstract}
Valdomiro Silveira reduces his narrative "Salvation" to a story of animals. Nevertheless, it is not a fable. This tale can be included in the set of works that, afraid to express eroticism, conceals love with fear. "A hora e vez de Augusto Matraga" does not disguise eroticism and gives sense to the characters and to the text, interwaving a few little genres; the so-called saga nordestina (Brazilian northest saga, in fact cordel); hagiography; the theme of the "Erring Jew" and the parable. The power of Sagarana's tales comes from the systematic utilization of the little genres, found in orality. They work as a basis both for the production and the reception of texts and enunciations. Orality, which serves to show the hick as capable of deep spirituality, is also a supporting resource of the religious secret.
\end{abstract}

KEYWORDS: Regionalism; orality; simple forms; love and fear; compared literature. 

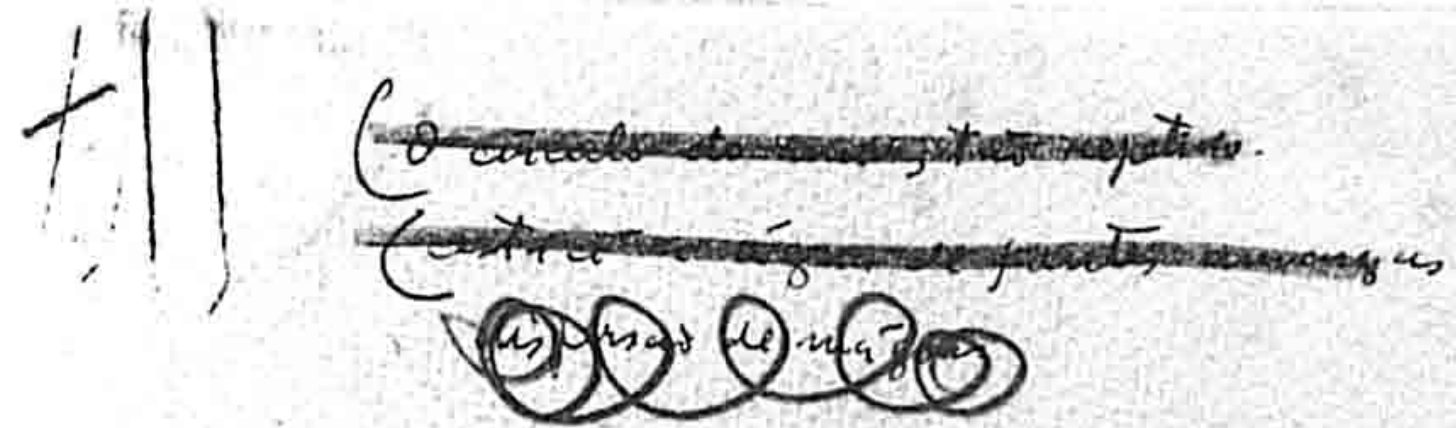

Ulens ossos que has de ne deverta. Kei de dar bum no. Rexerlores indefuin-sue e is

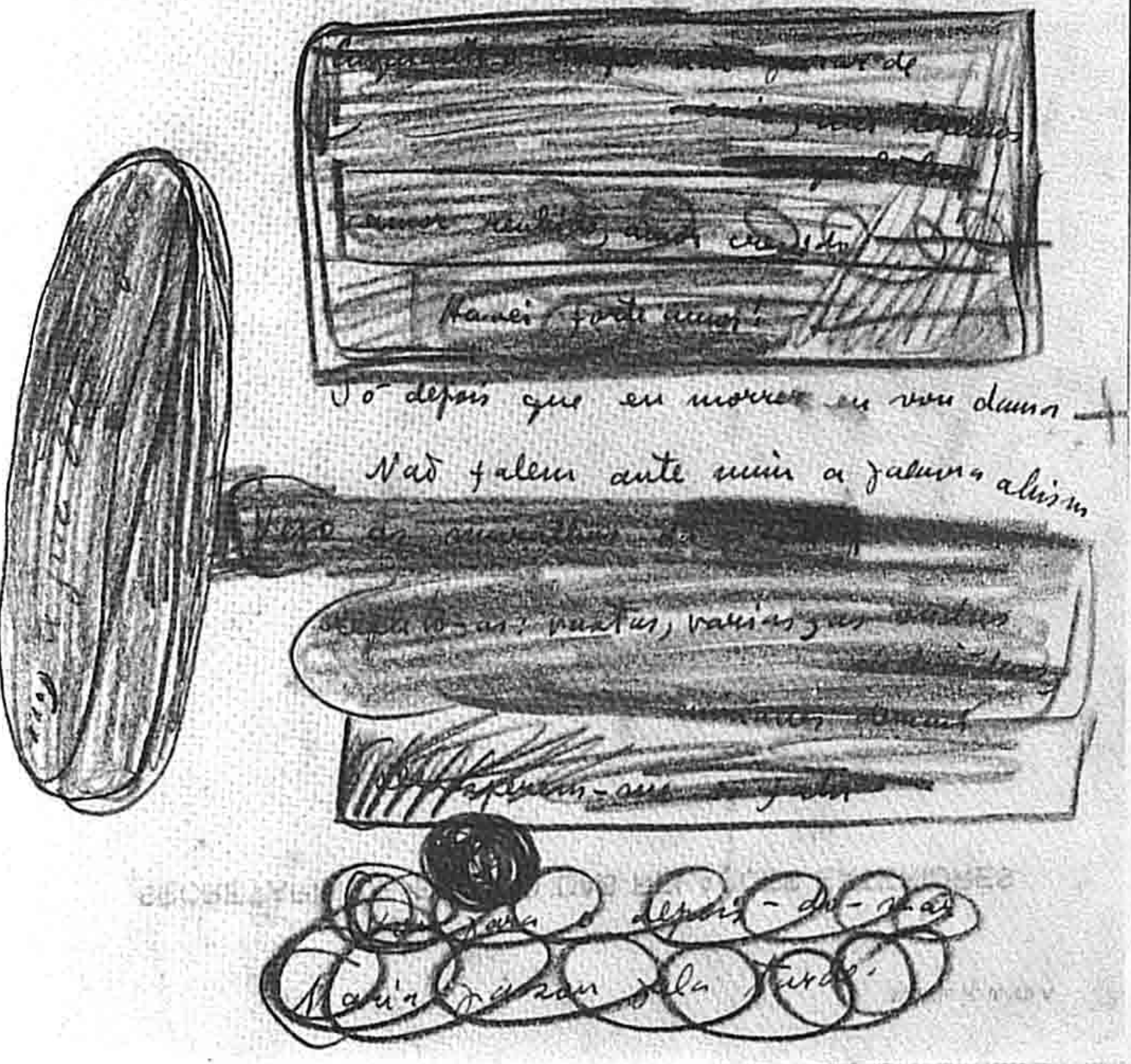

Manuscrito. Arquivo IEB. 


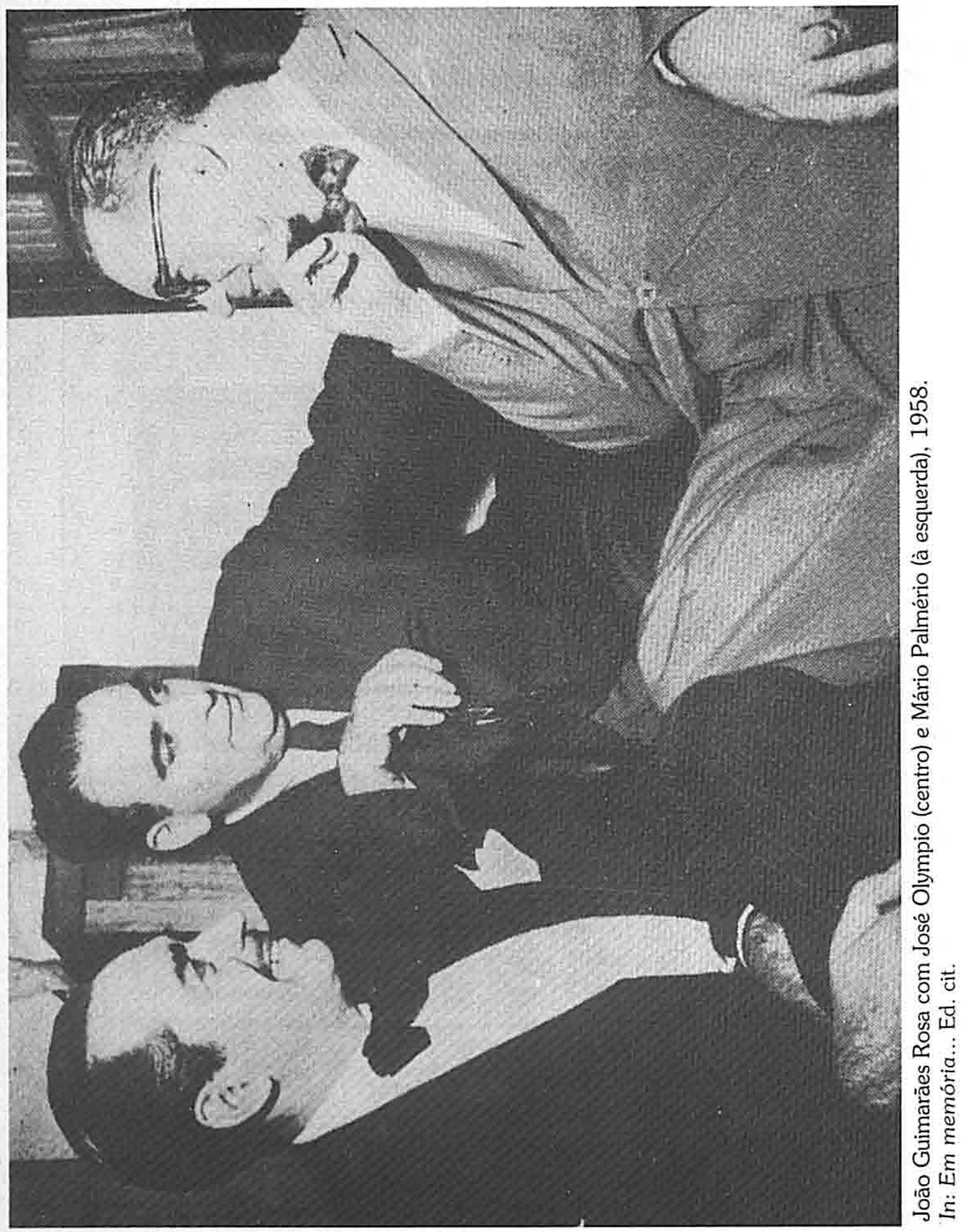

